Click www.researchjournal.co.in/online/subdetail.html to purchase.

Volume 5 | Issue 2 | September, 2014 | 176-178 — e ISSN-2231-6434|

International Research Journal of Agricultural Economics and Statistics

Visit Us - www.researchjournal.co.in DOI : 10.15740/HAS/IRJAES/5.2/176-178

\title{
Research Paper Price spread in marketing of grapes in Pune district of Maharastra
}

M.D. JAGTAP

Author for Correspondence :

\section{M.D. JAGTAP}

Agricultural Economics

Section, Padmashree Dr.

D.Y. Patil College of

Agriculture Business

Management, AKRUDI,

PUNE (M.S.) INDIA

\section{Paper History :}

Received : 02.04.2014;

Revised : 30.06 .2014 ;

Accepted: 17.07 .2014
ABSTRACT : The focus of the present study was on marketing management of grape in Pune district of Maharashtra. A sample size of 90 farmers and 30 market intermediaries was selected using proportionate random sampling method. Field level data were elicited for the agriculture year 2012-13 through personal interview method. The grading, packaging, transport and commission charges were the major important cost. The per $\mathrm{kg}$. cost of transportation was Rs. 0.83. The commission of intermediaries was Rs. 2.90 per $\mathrm{kg}$. The per $\mathrm{kg}$. marketing cost for $20 \mathrm{~kg}$. crate, $5 \mathrm{~kg}$. box and $2 \mathrm{~kg}$. box was worked out to Rs. 4.39, Rs.5.70, and Rs. 5.20, respectively. It was observed that at the overall level about 37.78 per cent growers preferred channel IV (Producer - Pre-harvest contractors-Retailer-Consumer) and also quantity sold was large, which is 59.32 per cent. Channel III and IV was generally followed to market the grapes to outside state market and to within state markets and quantity marketed was 28.15 and 36.76 per cent, respectively. The producers shares in consumers rupees in case of channel - I, II and IV was 71.06, 61.70 and 63.48 per cent, respectively.

KEY WORDS : Marketing channels, Cost, Margins, Price spread, Grapes

HOW TO CITE THIS PAPER : Jagtap, M.D. (2014). Price spread in marketing of grapes in Pune district of Maharastra. Internat. Res. J. Agric. Eco. \& Stat., 5 (2) : 176-178. 